\title{
PENGARUH SERVICESCAPE TERHADAP LOYALITAS TAMU MANCANEGARA DI ALAM KULKUL BOUTIQUE RESORT BALI
}

\author{
Ghea Astri Yuliantina \\ Gitasiswhara \\ Manajemen Pemasaran Pariwisata FPIPS UPI
}

\begin{abstract}
ABSTRAK
Untuk menjaga eksistensi hotel di tengah dampak buruk persaingan dalam industri perhotelan, loyalitas tamu sangat diperlukan. Menurunnya jumlah tamu mancanegara yang loyal terhadap Alam Kulkul Boutique Resort Bali mengindikasikan adanya masalah yang harus dicari strategi untuk mengatasinya. Melalui servicescape yang bertema natural and traditional of Bali diharapkan dapat mempertahankan dan meningkatkan loyalitas tamu mancanegara di Alam Kulkul Boutique Resort Bali. Penelitian ini bertujuan untuk mengetahui servicescape yang ada di Alam Kulkul Boutique Resort Bali, loyalitas tamu mancanegara dan pengaruh servicescape terhadap loyalitas tamu mancanegara. Dalam penelitian ini, variabel bebas $(X)$ yang digunakan yaitu servicescape yang terdiri dari ambient conditions, spatial layout and functionality, dan signs, symbols and artifacts. Variabel terikat (Y) yaitu loyalitas. Penelitian ini dilakukan selama lima bulan yakni bulan Desember 2011 sampai dengan bulan Mei 2012 dengan menggunakan teknik sampling stratified random sampling dan analisis jalur sebagai teknis analisis datanya. Kuesioner diberikan kepada 100 tamu mancanegara yang menginap di Alam Kulkul Boutique Resort Bali. Hasil penelitian menunjukkan servicescape di Alam Kulkul Boutique Resort Bali berada di kategori tinggi. Spatial layout and functionality sebagai salah satu bagian dari servicescape mendapatkan respon paling baik dan skor nilai paling tinggi. Loyalitas tamu mancanegara di Alam Kulkul Boutique Resort Bali juga berada pada kategori tinggi. Tamu mancanegara di Alam Kulkul Boutique Resort Bali memiliki tingkat behavioral yang lebih tinggi dibandingkan tingkat attitudinal sehingga mayoritas tamu mancanegara memiliki karakteristik spurious loyalty. Servicescape berpengaruh terhadap loyalitas tamu mancanegara. Pengaruh terbesar servicescape terhadap loyalitas tamu mancanegara diperoleh melalui spatial layout and functionality dan pengaruh terkecil diperoleh melalui signs, symbols and artifacts. Saran kepada Alam Kulkul Boutique Resort Bali yaitu agar dapat meningkatkan implementasi signs, symbols and artifacts dan melakukan upaya untuk meningkatkan loyalitas tamu mancanegara terutama faktor-faktor pada tingkat attitudinal tamu mancanegara.
\end{abstract}

Kata kunci: servicescape, loyalitas

\section{PENDAHULUAN}

1.1 Latar Belakang Penelitian

Sektor pariwisata merupakan salah satu sektor industri terbesar di dunia (World Travel \& Tourism Council Annual Report 2011). Di negara-negara berkembang, sektor industri pariwisata menjadi faktor pendorong dalam meningkatkan pertumbuhan ekonomi mereka, mengingat pertumbuhan pariwisata global yang cenderung terus meningkat tiap tahunnya. Indonesia merupakan salah satu negara yang memanfaatkan sektor industri ini untuk mendorong pertumbuhan perekonomiannya. Berdasarkan data statistik tahun 2011 dalam website Kementerian Pariwisata dan Ekonomi Kreatif Indonesia (Kemenparekraf) perkembangan pariwisata Indonesia pada tahun 2009 sampai tahun 2011 terus mengalami peningkatan. Indonesia memiliki beberapa destinasi wisata utama yang memiliki keunikannya masing-masing. Salah satunya adalah Bali. Bali masih menjadi destinasi utama pilihan para wisman, karena Bandara Ngurah Rai Bali selalu menjadi pintu masuk yang memiliki jumlah kedatangan wisman terbanyak diantara 19 pintu masuk utama lainnya (Data statistik Kemenparekraf 2006-2011).

Sejalan dengan meningkatnya jumlah kedatangan wisatawan ke Bali, jumlah akomodasi di Pulau Bali juga turut bertambah. Pada tahun 2011 terjadi pergeseran pasar dimana banyaknya wisatawan lebih memilih untuk menginap di akomodasi non bintang. Hal tersebut dapat terlihat pada dimana presentase rata-rata tingkat hunian kamar hotel berbintang pada tahun 2011 mengalami penurunan. Krisis ekonomi yang terjadi di Eropa dan Amerika pada penghujung tahun 2011 menjadi salah satu penyebabnya. Kebanyakan wisman harus lebih mengatur anggaran biaya berliburnya dengan mencari akomodasi yang lebih murah tetapi memiliki fasilitas yang setaraf dengan hotel berbintang. 
Alam Kulkul Boutique Resort Bali memiliki tema khusus dengan menggunakan konsep boutique resort sebagai pembeda dari hotel maupun resort bintang empat lainnya. Market share yang dicapai Alam Kulkul Boutique Resort Bali sampai tahun 2011 yaitu sebesar $6,11 \%$ dari keseluruhan jumlah hotel dan resort bintang empat yang terletak di Kuta dan Legian, yakni sebanyak tujuh hotel (Andizar, wawancara, 23 September 2011). Jumlah presentase tersebut merupakan jumlah paling kecil. Namun, hal yang terpenting adalah bagaimana membuat tamu yang sudah pernah menginap di Alam Kulkul Boutique Resort Bali agar mau kembali menginap berulang kali secara teratur (repeater), memiliki komitmen yang tinggi dan sikap positif terhadap hotel sehingga tamu tersebut dapat merekomendasikan kepada orang lain untuk menginap di Alam Kulkul Boutique Resort Bali. Tamu dengan karakteristik tersebut dapat diindikasikan sebagai tamu yang memiliki loyalitas.

Berdasarkan hasil wawancara dengan Executive Assistant Manager, tamu loyal pada resort ini memiliki karakteristik dimana tamu tersebut sudah pernah menginap lebih dari dua kali dan kembali menginap minimal satu kali dalam satu tahun. Berbagai keuntungan yang bisa didapatkan dari seorang tamu yang loyal disadari betul oleh pihak manajemen Alam Kulkul Boutique Resort. Peningkatan jumlah tamu loyal yang kembali menginap di Alam Kulkul Boutique Resort tentunya sangat diharapkan.

Jumlah tamu loyal di Alam Kulkul Boutique Resort Bali terus mengalami fluktuasi. Tahun 2009 dengan jumlah tertinggi pada lima tahun terakhir yaitu sebesar 2469 tamu loyal tidak berhasil ditingkatkan pada tahun-tahun berikutnya. Jumlah tersebut terus menurun sebesar 8,2\% di tahun 2010 dan kembali menurun sebesar 3\% di tahun 2011 menjadi 2198 tamu. Presentase penurunan yang cukup tinggi mengingat pihak manajemen Alam Kulkul Boutique Resort Bali telah menargetkan jumlah tamu loyal yang kembali menginap di tahun 2011 dapat meningkat $10 \%$ dari jumlah tamu loyal tahun 2010. Namun target tersebut gagal tercapai.

Tamu loyal mancanegara mendominasi jumlah tamu loyal di alam Kulkul Boutique Resort Bali sebesar 88,93\%. Sementara jumlah tamu yang berasal dari Indonesia hanya sebesar $11,07 \%$ atau 243 tamu. Diantara tamu-tamu tersebut rata-rata lama menginap yaitu selama empat malam. Tamu mancanegara yang menginap didominasi oleh tamu yang berasal dari Australia dengan presentase sebesar 47,32\% atau 1.040 tamu. Kemudian Jepang berada di peringkat ke tiga setelah Indonesia dan disusul wisatawan Eropa pada peringkat ke empat. Hal itu sesuai dengan target pasar utama dari Alam Kulkul Boutique Resort Bali yang merupakan wisatawan Australia, Jepang dan Eropa. Berdasarkan hal tersebut dan didominasinya tamu loyal mancanegara yang menginap di Alam Kulkul Boutique Resort Bali pada tahun 2011, maka penelitian ini difokuskan hanya kepada tamu mancanegara yang pernah menginap lebih dari dua kali dan kembali menginap minimal satu kali dalam setahun.

Pada umumnya wisatawan mancanegara ingin mendapatkan pengalaman berlibur yang tidak dapat mereka rasakan di negara masingmasing. Tidak hanya pengalaman berlibur dalam menikmati destinasi wisatanya saja, tetapi juga pengalaman yang didapatkan pada hotel tempat mereka menginap yang dapat memberikan kesan suasana khas Bali yang juga tidak didapatkan dan dirasakan di negara mereka. Pengalaman tersebut dapat ditemukan di Alam Kulkul Boutique Resort Bali. Karena berbagai hal-hal fisik hingga cara melayani tamu yang ada pada resort ini mengacu pada budaya Bali yang biasa ditemukan pada kehidupan sehari-hari masyarakat pedesaan di Bali.

Jasa bersifat tidak berwujud, untuk itu hal-hal fisik yang berada di dalam atau di luar bagian hotel memiliki peran penting dalam memberikan sinyal-sinyal kepada tamu hotel mengenai jenis dan kualitas jasa yang akan disampaikan. Hal tersebut pula yang memiliki pengaruh besar terhadap perasaan seseorang yang merupakan salah satu reaksi yang mendorong atau memaksa seseorang untuk tetap berada ditempat tersebut atau pergi meninggalkannya (Russel \& Ward 1982; Alsaqre et al. 2010). Bahkan Han dan Ryu (2009:514) menyatakan bahwa dekorasi dan artifacts, spatial layout dan ambient conditions memiliki peran independen yang signifkan dalam membentuk loyalitas pelanggan.

Keseluruhan aspek fisik di Alam Kulkul Boutique Resort Bali bertemakan natural and traditional of Bali. Berbagai fasilitas fisik pendukung jasa baik di kamar maupun di public area dan desain interior maupun eksterior di resort ini mendapatkan respon yang baik dari para tamu mancanegaranya. Berdasarkan data front office department yang menunjukkan hasil rekapitulasi guest comment berdasarkan tanggapan tamu mancanegara 
yang menginap selama tahun 2011. Dari 1873 tamu mancanegara yang mengisi guest comment, peringkat tiga tertinggi didominasi oleh aspek fisik seperti resort ambience (72\% sangat baik) dan desain interior dan eksterior (66\% sangat baik). Sementara aspek pelayanan kamar berada di peringkat ke-3 dengan presentase $62 \%$ pada kategori nilai sangat baik.

Respon yang diberikan tamu mancanegara melalui guest comment menunjukkan bahwa aspek lingkungan fisik di Alam Kulkul Boutique Resort Bali berhasil menarik perhatian para tamu mancanegara yang menginap secara positif. Mempertahankan aspek tersebut tentunya diperlukan, namun meningkatkannya merupakan hal yang lebih penting mengingat beragam respon internal positif yang bisa didapatkan resort dari para tamu yang menginap. Respon tersebut diantaranya kepercayaan, kenyamanan, suasana hati yang lebih baik, rasa aman dan lainnya. Sehingga tamu akan memberikan reaksi terhadap respon internal tersebut berupa perilaku yang lebih menguntungkan resort seperti, menginap lebih lama, kembali menginap setelah kunjungan pertama, mengeluarkan uang yang lebih banyak atau bahkan meningkatkan loyalitas mereka terhadap resort ini (Bitner 1992; Wakefield dan Blodget 1999; Han dan Ryu 2009; Alsaqre et al. 2010; Lovelock dan Wirtz 2011)

Dalam istilah pemasaran, berbagai bentuk lingkungan fisik beserta komponenkomponennya seperti suasana (ambience) maupun desain interior disebut dengan servicescape. Menurut Lovelock dan Wirtz (2011:277) servicescape berkaitan dengan gaya dan wujud dari lingkungan fisik dan elemen-elemen eksperiental lainnya yang ditemukan oleh pelanggan di tempat jasa tersebut disampaikan. Sadar akan berbagai respon positif yang dapat diberikan oleh tamu resort melalui implementasi servicescape, Executive Assistant Manager yaitu Bapak Hery Andizar dalam wawancaranya mengatakan bahwa servicescape merupakan strategi utama yang digunakan untuk meningkatkan loyalitas para tamunya, khususnya tamu mancanegara (wawancara, 23 September 2011).

Servicescape atau wujud lingkungan fisik Alam Kulkul Boutique Resort Bali mencerminkan suasana pedesaan Bali. Ambient conditions, spatial layout and functionality dan, signs symbols and artifact sebagai bagian dari servicescape diimplementasikan secara menyeluruh pada setiap sudut ruangan Alam Kulkul Boutique Resort Bali. Berikut adalah servicescape yang digunakan di Alam Kulkul Boutique Resort Bali.

Servicescape yang dimiliki Alam Kulkul Boutique Resort Bali merupakan salah satu strategi pemasaran yang diduga mampu meningkatkan tingkat loyalitas tamu mancanegara di Alam Kulkul Boutique Resort Bali. Karena jumlah tamu mancanegara yang menginap terus menurun sejak tahun 2009. Berdasarkan latar belakang di atas maka perlu adanya suatu penelitian mengenai "Pengaruh Servicescape terhadap Loyalitas Tamu Mancanegara di Alam Kulkul Boutique Resort Bali.

\subsection{Rumusan Masalah}

Berdasarkan latar belakang di atas, maka dapat dirumuskan beberapa masalah penelitian sebagai berikut:

1. Bagaimana servicescape yang ada di Alam Kulkul Boutique Resort Bali.

2. Bagaimana loyalitas tamu mancanegara di Alam Kulkul Boutique Resort Bali.

3. Bagaimana tingkat loyalitas tamu mancanegara di Alam Kulkul Boutique Resort Bali.

4. Sejauh mana pengaruh servicescape yang terdiri atas ambient conditions, spatial layout and funcionality, signs symbols and artifact terhadap loyalitas tamu mancanegara Alam Kulkul Boutique Resort Bali.

\subsection{Tujuan Penelitian}

Berdasarkan rumusan masalah di atas, maka tujuan dari penelitian ini adalah untuk memperoleh hasil temuan mengenai:

1. Servicescape yang ada di Alam Kulkul Boutique Resort Bali.

2. Loyalitas tamu mancanegara di Alam Kulkul Boutique Resort Bali.

3. Tingkat loyalitas tamu mancanegara di Alam Kulkul Boutique Resort Bali.

4. Pengaruh servicescape yang terdiri atas ambient conditions, spatial layout and funcionality, dan signs symbols and artifact terhadap loyalitas tamu mancanegara Alam Kulkul Boutique Resort Bali.

\subsection{Kegunaan Penelitian}

1. Kegunaan Teoritis 
Hasil penelitian ini diharapkan dapat memperluas kajian ilmu pemasaran pariwisata khususnya mengenai servicescape dan pengaruhnya terhadap loyalitas, serta dapat memberikan masukan bagi peneliti dalam mengembangkan ilmu pemasaran pariwisata pada bidang industri perhotelan.

2. Kegunaan Praktis

Secara praktis hasil penelitian ini diharapkan dapat memberikan masukan bagi Alam Kulkul Boutique Resort Bali dalam upaya meningkatkan loyalitas tamu melalui servicescape.

\section{KERANGKA PEMIKIRAN}

\subsection{Servicescape}

Kotler dan Keller (2011:3) memberikan definisi pemasaran sebagai "seni dan pengetahuan dalam memilih target pasar dan mendapatkan, mempertahankan dan mengembangkan pelanggan melalui, penciptaan, penyampaian, dan mengkomunikaskan nilai pelanggan superior". Industri jasa merupakan salah satu industri yang juga melakukan pemasaran demi mengkomunikasikan nilai-nilai jasa kepada pelanggannya.

Hoffman dan Bateson (2011:78-79) dalam bukunya yang berjudul "Service Marketing: Concepts, Strategies \& Cases" memberikan aspek tambahan pada bauran pemasaran khususnya untuk perusahaan jasa. Bauran pemasaran tradisional yang pada awalnya terdiri dari empat aspek (product, price, place, dan promotion) dalam bauran pemasaran jasa menjadi tujuh aspek pokok yaitu product, price, place, promotion, people, process, dan physical evidence.

Fandy (2006:32) berpendapat bahwa karakteristik jasa yang bersifat intangible menyebabkan pelanggan potensial tidak bisa menilai suatu jasa sebelum mengkonsumsinya. Pelanggan sering mengandalkan tangible cues dalam mengevaluasi sebuah jasa sebelum membelinya dan menilai kepuasannya selama dan setelah dikonsumsi. Oleh sebab itu physical evidence atau bukti fisik dari karakteristik jasa merupakan salah satu unsur penting dalam pemasaran jasa. Zeithaml et al. (2009:313) mengemukakan secara umum bukti fisik jasa meliputi semua aspek fasilitas fisik organisasi (servicescape) dan juga bentuk komunikasi fisik lainnya.
Sebagai bagian dari physical evidence, servicescape merupakan gaya dan wujud dari lingkungan fisik dan elemen-elemen eksperiental lainnya yang ditemukan oleh pelanggan di tempat jasa tersebut disampaikan (Lovelock dan Wirtz 2011:277). "Semua yang secara fisik ada di sekitar pelanggan selama proses transaksi service encounter disebut servicescape." (Hightower 2009:381). "Servicescape merujuk pada pemakaian bukti fisik untuk mendesain lingkungan jasa" (Hoffman dan Bateson 2011:9). Menurut Lovelock dan Wright (2007:214), "Servicescape merupakan kesan-kesan yang diciptakan pada pancaindera oleh perancangan lingkungan fisik tempat jasa diserahkan". Berdasarkan beberapa definisi ahli mengenai servicescape, penulis menyimpulkan bahwa servicescape merupakan lingkungan fisik yang ada disaat jasa disampaikan kepada pelanggan dan memiliki elemen-elemen tertentu yang masih berhubungan dengan konsep jasa tersebut.

Servicescape merupakan penampilan luar dari organisasi dan penting untuk menciptakan kesan pertama atau membangun harapan bagi pelanggan (Simpeh et al. 2011:120). Kemampuannya untuk menciptakan kesan positif atau negatif terhadap masing-masing pancaindera menyebabkan makin banyak perusahaan memberikan perhatian penuh terhadap desain perusahaannya. Selain itu servicescape sangat penting untuk customer experience karena lingkungan tersebut memberikan tanda maupun sinyal-sinyal tangible maupun intangible akan jasa yang akan disampaikan kepada konsumen.

Dalam penelitiannya Bitner (Han dan Ryu 2009:589) menjelaskan bahwa semua faktor-faktor fisik yang dapat dikendalikan oleh perusahaan jasa dibuat untuk meningkatkan respon internal dari pelanggan (kognitif, emosi, kepuasan dan lainnya) juga respon eksternalnya (tetap berada difasilitas jasa, kembali membeli, atau pendekatan). Desain servicescape juga dapat mempengaruhi pilihan pelanggan, ekspektasi pelanggan, kepuasan pelanggan dan lainnya (Fandy 2006:144). Wakefield dan Blodgett (Simpeh et al. 2011:124) mengemukakan bahwa "semakin lama seseorang berada di suatu fasilitas maka semakin besar kemungkinan kualitas yang dirasakan dari servicescape memainkan peranan penting dalam menentukan kepuasan jasa". Begitu juga dengan pendapat Simpeh et al. (2011:125) yang menyatakan "semakin lama 
seseorang berada di suatu fasilitas maka kemungkinan uang yang dibelanjakan akan semakin besar".

Berdasarkan Hofman dan Bateson (2011:202-204) pemahaman mengenai servicescape sangat penting bagi pemasar jasa, karena servicescape bisa memainkan beberapa peranan sekaligus, yaitu sebagai package, facilitator, socializer, dan differentiator. Fasilitas fisik perusahaan pada hakikatnya "mengemas" jasa yang ditawarkan dan mengkomunikasikan citra eksternal serta kualitas jasa yang akan disampaikan kepada pelanggan. Servicescape juga berperan besar dalam memfasilitasi aliran aktivitas yang memproduksi jasa. Fasilitas fisik bisa menyediakan informasi kepada pelanggan mengenai cara kerja proses produksi jasa.

Desain servicescape berperan besar dalam proses sosialisasi melalui pengkomunikasian nilai-nilai, norma, perilaku, peran, dan pola hubungan antar karyawan, serta antara pelanggan dengan karyawan. Fasilitas fisik bisa digunakan penyedia jasa untuk mendiferensiasikan perusahaannya dari para pesaing dan mengomunikasikan tipe segmen pasar yang ingin dilayani. Perubahan lingkungan fisik juga bisa dimanfaatkan untuk melakukan repositioning dan/atau menarik segmen baru.

Beberapa ahli menjelaskan dimensi servicescape, namun penelitian ini menggunak dimensi dari Lovelock dan Wirtz (2011:284-290) yang membagi dimensi servicescape menjadi tiga bagian yaitu: Ambient conditions, merupakan karakteristik lingkungan yang berkenaan dengan kelima panca indera. Latar belakang dari lingkungan seperti suhu, pencahayaan, musik, warna, bau dan gangguan suara (Lovelock dan Wirtz, 2011; Zeithaml et al., 2006). Beberapa ganguan kecil mungkin tidak akan menggangu pelanggan namun jika kondisi lingkungan menjadi ekstrim dapat menjadi masalah serius dan membuat pelanggan tertekan. Spatial layout and functionality, merupakan denah ruangan, ukuran, dan bentuk dari perlengkapan perabot, meja-meja, mesin dan peralatan yang berpotensi dan cara mereka diatur juga kemampuan benda-benda tersebut untuk memfasilitasi kegiatan transaksi jasa. Pengaturan peralatan dan interior untuk visual dari tampilan fisik dan fungsi-fungsi yang bermanfaat untuk penyerahan atau pelayanan jasa. Tata ruang (spatial layout) mengacu pada bagaimana ruangan tersebut digunakan dan dimana furnitur dan peralatan ditempatkan dalam kamar. Skala dan ukuran properti perhotelan mempengaruhi tata ruang. Fungsionalitas mengacu pada efektivitas tata ruang untuk memfasilitasi pelayanan yang efisien dan memberikan kepuasan pelanggan. Tata ruang harus mencapai keseimbangan optimal antara persyaratan operasional dan harapan pelanggan. Signs, symbols, and artifacts, tanda-tanda atau simbol juga bentuk bangunan yang mampu mengkomunikasikan tampilan bagi pelanggan. Segala sesuatu yang ada di lingkungan jasa yang berperan sebagai sinyal secara langsung maupun tidak langsung untuk mengkomunikasikan citra perusahaan, membantu pelanggan menemukan arahnya, dan untuk menyampaikan proses pelayanan jasa. Lovelock dan Wirtz (2011:298) menyebutkan sinyal langsung diantaranya label untuk mengindikasikan departemen tertentu, untuk menunjukkan arah, mengkomunikasikan skema jasa dan peraturan akan perilaku tertentu (behavioral rules sign)

\subsection{Loyalitas Pelanggan}

Berdasarkan jurnal Baloglu yang berjudul "Dimensions of Loyalty - Separating Friends From Well Wishers" dapat disimpulkan bahwa loyalitas merupakan sikap dan perilaku pelanggan yang menunjukkan adanya pembelian berulang akan suatu barang atau jasa selain itu juga menunjukkan komitmen yang tinggi pada merek atau perusahaan tersebut (2002:47). Penelitian ini menggunakan teori loyalitas dari Baloglu sebagai acuan penelitian.

Pendekatan sikap loyalitas mencerminkan loyalitas meliputi hal yang lebih dari sekedar pembelian ulang. Pendekatan ini menegaskan bahwa loyalitas pelanggan melibatkan sikap yang mencerminkan komitmen setiap waktu. Dengan kata lain, loyalitas pelanggan merupakan respon perilaku terhadap sikap pada suatu produk. Untuk memahami sikap loyalitas, perusahaan harus dapat menjelaskan kepada pelanggan mengenai informasi atau keyakinan yang sebenarnya mengenai produk, sehingga pelanggan dapat memahami produk dan merasa yakin akan produk tersebut.

$$
\text { Baloglu (2002:48-49) juga }
$$

mengungkapkan dua pendekatan dasar loyalitas pelanggan yang didasari oleh perilaku (behavioral) dan sikap (attitudinal). Pendekatan loyalitas sebagai perilaku meliputi konsistensi pelanggan dalam melakukan pembelian ulang. Sementara loyalitas sebagai sikap ditunjukkan dengan adanya komitmen atau ikatan emosional terhadap merek atau perusahaan tersebut. Baloglu (2002:48-49) 
membagi loyalitas dalam empat segmen tipologi yang didapatkan dari gabungan tingkat perilaku dan sikap loyalitas tersebut, yaitu:

1. True loyalty (Loyalitas sejati) yaitu pelanggan yang memiliki perilaku pembelian ulang yang tinggi dan sikap komitmen yang tinggi terhadap merek dan perusahaan. Mereka yang memiliki loyalitas sejati hampir selalu membeli dari perusahaan atau merek tertentu dan paling tidak rentan dengan tawaran-tawaran yang diberikan oleh pesaing.

2. Latent loyalty (Loyalitas tersembunyi) yaitu perilaku pelanggan yang memiliki tingkat pembelian berulang yang rendah walaupun mereka memiliki sikap komitmen yang kuat terhadap perusahaan. Frekuensi pembelian berulang yang rendah dapat terjadi karena tidak adanya sumber yang cukup untuk meningkatkan frekuensi pembelian mereka yang dapat mendorong mereka menjadi repeat customer seperti karena harga, aksesibilitas, atau strategi distribusi.

3. Spurious loyalty (Loyalitas palsu), yaitu perilaku pelanggan yang memiliki frekuensi pembelian berulang yang tinggi namun tidak ada ikatan emosional atau komitmen tertentu pada perusahaan. Tingginya frekuensi pembelian berulang dapat terjadi karena beberapa faktor seperti kebiasaan membeli, kemudahan, keuangan, kurangnya alternatif produk, dan faktor-faktor yang berhubungan dengan situasi pembeli.

4. Low loyalty (Loyalitas yang rendah/ tidak ada loyalitas), pada tahapan ini perilaku pembelian berulang dan sikap komitmen sangat rendah. Loyalitas palsu dan loyalitas rendah sangat rentan terhadap tawaran yang diberikan pesaing.

5. Beberapa peneliti menyebutkan bahwa loyalitas merupakan konsep multidimensional yang melibatkan elemen perilaku (behavioral elements) dan elemen sikap (attitudinal elements) (Baloglu 2002:49). Penelitian yang hanya menggunakan pendekatan perilaku tidak dapat menangkap alasan dibalik pembelian yang dilakukan pelanggan. Apakah mereka membeli hanya karena kebiasaan atau kemudahan, atau mereka membeli karena mereka memang memiliki ikatan emosional dengan perusahaan atau merek tersebut. Begitu juga yang terjadi apabila peneliti hanya meneliti dari pendekatan sikap. Peneliti tidak akan mengetahui seberapa besar efek persaingan (seperti loyalitas yang terbagi, multi-merek), pengetahuan pelanggan akan merek atau perusahaan dan faktor-faktor situasi lainnya (Baloglu 2002:49).

Baloglu (2002:50-51) menjelaskan loyalitas yang dilihat dari dua indikator perilaku (behavioral) dan sikap (attitudinal). Berikut adalah faktor-faktor yang dapat mengukur tingkat perilaku;

1. Frekuensi kunjungan

2. Waktu yang dihabiskan dalam satu kali kunjungan

3. Kerjasama.

Keinginan pelanggan dalam melakukan kerjasama dengan perusahaan demi tercapainya tujuan bersama (memberikan saran atau menawarkan ide-ide kepada perusahaan demi membuat perusahaan menjadi lebih baik)

4. Word-of-mouth.

Memberikan rekomendasi (word-ofmouth) termasuk mempromosikan perusahaan, membuat komentar-komentar positif dan rujukan bisnis.

Berikut adalah faktor yang dapat mengukur tingkat sikap;

1. Trust (Kepercayaan).

Kepercayaan merupakan elemen-elemen yang terdiri dari kejujuran (memenuhi janji), kemampuan, kebaikan, keandalan dan customer orientation.

2. Emotional attachment/commitment (Ikatan emosi atau komitmen).

Komitmen dapat berarti adanya rasa memiliki terhadap perusahaan sehingga pelanggan mau dan menikmati proses kerjasama yang dilakukan.

3. Switching cost (Biaya peralihan)

Waktu, usaha, dan biaya yang harus dikeluarkan pelanggan jika ingin beralih menggunakan produk atau jasa pesaing.

Dapat disimpulkan berdasarkan indikator tersebut pelanggan yang memiliki loyalitas yang tinggi tentunya harus memiliki sikap dan perilaku yang tinggi terhadap produk, merek atau perusahaan. Kerjasama yang terjalin baik antara perusahaan dengan pelanggan loyal akan menguntungkan kedua belah pihak. Untuk itu perusahaan diharapkan mampu mengidentifikasi faktor-faktor dibalik rasa loyal yang dimiliki pelanggan mereka. Penelitian ini menggunakan dimensi loyalitas yang dikemukakan oleh Baloglu dalam mengukur loyalitas tamu yang dalam hal ini adalah tamu loyal mancanegara.

Perusahaan yang memiliki pelanggan loyal akan memperoleh keuntungan- 
keuntungan seperti yang diungkapkan oleh Griffin (2005:11): Keuntungan-keuntungan yang akan diperoleh perusahaan apabila memiliki pelanggan yang loyal antara lain mengurangi biaya pemasaran, mengurangi biaya transaksi, mengurangi biaya turn over pelanggan, meningkatkan penjualan silang yang akan memperbesar pangsa pasar perusahaan, dan word of mouth yang lebih positif, dan mengurangi biaya kegagalan.

\subsection{Hipotesis}

Berdasarkan premis-premis di atas, maka hipotesis dalam penelitian ini adalah "Terdapat pengaruh antara servicescape yang terdiri dari ambient conditions, spatial layout and functionality dan signs, symbols and artifacts terhadap loyalitas tamu mancanegara di Alam Kulkul Boutique Resort Bali’”.

\section{METODE PENELITIAN}

Objek penelitian yang menjadi independent variabel atau variabel bebas (variabel X) yaitu servicescape terdiri dari ambient conditions (X1), spatial layout and functionality (X2), dan signs, symbols and artifacts (X3). Selanjutnya yang menjadi dependent variabel atau variabel terikat (Variabel Y) yaitu loyalitas yang terdiri dari behavioral dan attitudinal. Responden dari penelitian ini adalah tamu mancanegara yang menginap secara berulang di Alam Kulkul Boutique Resort Bali. Penelitian ini menggunakan pendekatan cross sectional karena dilakukan dalam waktu kurang dari satu tahun. Cross sectional method adalah metode penelitian yang mempelajari objek dalam kurun waktu tertentu (tidak berkesinambungan dalam jangka waktu panjang) (Sugiyono 2008:8). Penelitian dilakukan dari bulan Januari hingga Mei 2012. Dalam menggunakan metode ini diharapkan peneliti dapat mengungkapkan dan mengkaji seberapa besar pengaruh servicescape terhadap loyalitas tamu mancanegara di Alam Kulkul Boutique Resort Bali.

Berdasarkan penjelasan dan bidang penelitian, maka jenis penelitian ini adalah penelitian deskriptif dan verifikatif, dimana dalam penelitian ini akan diuji apakah servicescape berpengaruh pada loyalitas tamu mancanegara di Alam Kulkul Boutique Resort Bali. Berdasarkan jenis penelitiaannya yaitu penelitian deskriptif dan verifikatif maka metode yang digunakan dalam penelitian ini adalah survey explanatory.

Populasi dalam penelitian ini adalah tamu mancanegara yang menginap di Alam
Kulkul Boutique Resort Bali sepanjang tahun 2011 yaitu sebanyak 1955 orang. Tamu mancanegara tersebut adalah tamu yang pernah menginap di Alam Kulkul Boutique Resort Bali lebih dari dua kali dan kembali menginap minimal satu kali dalam setahun. Secara umum, masing-masing tamu loyal mancanegara terbagi menjadi sembilan kategori berdasarkan negara asal.

Sampel yang digunakan dalam penelitian ini adalah sebagian dari populasi penelitian yaitu sebagian tamu mancanegara (loyal) yang menginap di Alam Kulkul Boutique Resort Bali pada periode tertentu. Berdasarkan hasil perhitungan di atas dengan menggunakan rumus Yamane dengan tingkat signifikansi sebesar $10 \%$ maka jumlah sampel untuk penelitian ini yaitu sebesar 100 orang. Jadi dalam penelitian ini jumlah sampel yang akan diambil berjumlah 100 orang tamu mancanegara yang terbagi atas. Masingmasing sampel yang diambil yakni diantaranya dari tamu Australia sebanyak 53 orang, tamu Jepang sebanyak 11 orang, tamu Malaysia sebanyak 9 orang, tamu Cina sebanyak 4 orang, tamu Amerika Serikat sebanyak 4 orang, tamu Inggris sebanyak 2 orang, tamu Jerman sebanyak 5 orang, Tamu Italia sebanyak 7 orang dan tamu Perancis sebanyak 5 orang.

Dalam penelitian ini tamu yang akan dijadikan sampel bersifat heterogen, dibedakan berdasarkan asal tinggal tamu. Sehingga untuk mendapatkan sampel representatif, maka dalam penelitian ini digunakan stratified random sampling atau sampel acak distratifikasi.

Rumus yang digunakan untuk menguji validitas menggunakan nilai korelasi antara data pada masing-masing pernyataan dengan skor total memakai teknik korelasi product moment, dikarenakan skala yang digunakan dalam penelitian ini adalah skala ordinal dan terdapat prasyarat pengolahan data yang menggunakan tehnik korelasi product moment sekurang-kurangnya merupakan data interval. Maka data dalam penelitian ini perlu untuk ditransformasi menjadi skala interval dengan menggunakan Method of Succesive Interval (MSI). Teknik korelasi menggunakan pearson product moment. Untuk proses perhitungannya dibantu dengan software PASW Statistics 18.

Berdasarkan hasil pengolahan data dengan menggunakan software PASW Statistics 18 yang menunjukkan item-item pernyataan dalam kuesioner valid kecuali item pernyataan nomor enam, karena $r$ Hitung item 
tersebut lebih kecil dibandingkan dengan $r$ Tabel yang bernilai 0,306 . Untuk itu item pernyataan nomor enam akan di drop dan dikeluarkan dari kuesioner. Berikut uji validitas instrumen penelitian.

Pengujian reliabilitas dalam penelitian ini menggunakan rumus Cronbach Alpha dengan bantuan software PASW Statistics 18 untuk proses penghitungannya. Pengujian reliabilitas instrumen dilakukan terhadap 30 responden dengan tingkat signifikansi $10 \%$ dan derajat kebebasan (dk) n-2 $(30-2=28)$ dengan menggunakan software komputer PASW Statistics 18, diketahui bahwa semua variabel reliabel, hal ini dikarenakan $\mathrm{C} \sigma$ masing-masing variabel lebih besar dibandingkan dengan koefisien alpha cronbach yang bernilai 0,700 .

Teknik analisis data yang digunakan untuk pengujian hipotesis dalam penelitian ini adalah analisis jalur (path analysis).

Keputusan penerimaan atau penolakan Ho

Rumusan Hipotesis operasional:

Ho : $P Y X_{1}=P Y_{2}=P Y X_{3}=0$

$H i$ : sekurang-kurangnya ada sebuah $P Y X i \neq 0, i=1,2$, dan 3

Kriteria pengambilan keputusan pengujian hipotesis secara statistik dalam rangka pengambilan keputusan penerimaan atau penolakan hipotesis dapat ditulis sebagai berikut :

$\boldsymbol{H}_{\boldsymbol{0}}$ artinya tidak terdapat pengaruh antara servicescape yang terdiri atas ambient conditions, spatial layout and functionality, dan signs symbols and artifact terhadap loyalitas tamu mancanegara di Alam Kulkul Boutique Resort Bali.

$\boldsymbol{H}_{\boldsymbol{I}}$ artinya terdapat pengaruh antara servicescape yang terdiri atas ambient conditions, spatial layout and functionality, dan signs symbols and artifact terhadap loyalitas tamu mancanegara di Alam Kulkul Boutique Resort Bali.

\section{HASIL PENELITIAN DAN PEMBAHASAN}

4.1 Gambaran Servicescape Alam Kulkul Boutique Resort Bali

\subsubsection{Ambient Conditions}

Berdasarkan hasil penelitian bahwa indikator-indikator dari ambient conditions yang mendapatkan penilaian tertinggi yaitu kesesuaian musik yang diperdengarkan dengan tema jasa yaitu tradisional Bali yaitu sebesar 15,5\%. Sesuai dengan pendapat Morrison dan Beverland dalam jurnal Lin dan Mattila (2010:825) yang mengemukakan bahwa latar belakang musik harus sesuai dengan lingkungan untuk meningkatkan posisi atau merek perusahaan di pasar. Menciptakan suasana menyenangkan melalui musik seperti menambah fitur yang menyenangkan pada produk atau jasa dan hasil yang didapat akan lebih kepada evaluasi terhadap lingkungan yang lebih positif (Han dan Ryu, 2009:494). Tingginya presentase pada indikator kesesuaian musik dengan tema jasa dikarenakan Alam Kulkul Boutique Resort Bali yang memiliki konsep resort seperti di pedesaan Bali selalu memutar musik gamelan Bali sebagai latar belakang musik di seluruh public area kecuali di restoran Italia Papas Limoncello Cafe Bali.

Penilaian terendah dari ambient conditions yaitu ada pada indikator kenyamanan suhu di public area. Hal ini dikarenakan resort berada di kawasan pantai yang cukup panas dan faktor struktur bangunan resort yang tidak terletak dalam satu bangunan melainkan beberapa bangunan kecil yang dihubungkan dengan jalan-jalan setapak lalu ada beberapa bagian bangunan yang bersifat open air (Spa, Restoran Bunga Kelapa, dan The Veranda Bar) sehingga penggunaan pendingin udara tidak dapat maksimal.

\subsubsection{Spatial Layout and Functionality .}

Indikator-indikator dari spatial layout and funcionality yang mendapat penilaian tertinggi yaitu kenyamanan denah ruangan hotel yaitu sebesar 9,1\%. Meskipun luas tanah Alam Kulkul Boutique Resort Bali tidak seluas hotel-hotel lainnya yang ada di Kuta dan Legian, hanya $10000 \mathrm{~m}^{2}$, namun denah bangunan yang ada dapat memberikan kenyamanan kepada tamu loyal mancanegara yang menginap. Dengan lahan yang terbatas Alam Kulkul Boutique Resort Bali mampu mendesain denah dari mulai penempatan kamar, fasilitas hotel hingga taman-taman tropis dengan efektif, sehingga dapat membuat tamu merasa nyaman saat menginap ataupun melakukan aktivitas di dalam resort.

Penilaian terendah dari spatial layout and funcionality terdapat pada indikator daya tarik bentuk furnitur di public area (Lobi, Alam Club, restoran, spa, dll) dengan presentase sebesar 6,3\%. Meskipun public area masih menggunakan tema atau konsep jasa yang sama yaitu tradisional Bali, namun untuk penggunaan furnitur di public area lebih didominasi oleh furnitur-furnitur modern yang dapat dijumpai di hotel-hotel lainnya. Penggunaan furnitur yang sangat identik 
dengan tema tradisional Bali difokuskan hanya di private area.

\subsubsection{Signs, Symbols and Artifacts}

Indikator-indikator dari signs, symbols, and artifacts yang mendapatkan nilai tertinggi adalah kejelasan tanda petunjuk arah dengan presentase sebesar 27,1\%. Meskipun Alam Kulkul Boutique Resort Bali memiliki struktur bangunan yang terpisah-pisah, penempatan tanda petunjuk arah menuju kamar atau fasilitas tertentu selalu diletakkan di tempattempat yang dapat terlihat jelas oleh para tamu mancanegara. Indikator yang mendapatkan nilai terendah adalah kejelasan pesan yang disampaikan oleh behavioral rules sign (dilarang merokok, dilarang membuang sampah, dll) dengan presentase sebesar $16 \%$. Kebanyakan tamu mancanegara tidak merasakan kejelasan behavioral rules sign yang ada di fasilitas-fasilitas tertentu, sehingga para tamu tersebut harus menanyakan terlebih dahulu kepada staf terutama mengenai larangan-larangan atau aturan tertentu di fasilitas tersebut.

\subsubsection{Rekapitulasi Hasil Servicescape}

Presentase untuk variabel servicescape dihitung berdasarkan rumus Sugiyono (2010:94). Secara ideal skor yang diharapkan untuk jawaban tamu loyal mancanegara terhadap pertanyaan 1 sampai dengan 26 adalah 13000. Dari perhitungan diperoleh total skor sebesar 9576 atau 73,66\% dari skor ideal yaitu 13000. Hasil tersebut menunjukkan bahwa servicescape di Alam Kulkul Boutique Resort Bali yang dinilai oleh tamu mancanegara dapat dikatakan tinggi. Hal tersebut dikarenakan nilai tinggi yang diperoleh sub variabel spatial layout and functionality. Spatial layout and functionality di Alam Kulkul Boutique Resort Bali mampu memberikan kenyamanan kepada tamu mancanegaranya, oleh sebab itu tamu mancanegara Alam Kulkul Boutique Resort Bali memberikan nilai tinggi terhadap sub variabel tersebut.

Lingkungan jasa merupakan lingkungan yang penuh dengan tujuan karena lingkungan tersebut ada untuk memenuhi kebutuhan tertentu, untuk itu spatial layout and functionality dari suatu lingkungan fisik merupakan hal yang penting (Simpeh et al. 2011:123). Menurut Lovelock dan Wirtz (2011:289) spatial layout and functionality merupakan denah ruangan, ukuran dan bentuk dari perlengkapan perabot, meja-meja, mesin dan peralatan yang berpotensi serta cara mereka diatur juga kemampuan benda-benda tersebut untuk memfasilitasi kegiatan transaksi jasa.

Alam Kulkul Boutique Resort Bali mampu memanfaatkan lahan yang terbatas untuk membuat denah ruangan dengan cermat. Wakefield and Blodget dalam Han dan Ryu (2009:490) mengungkapkan, denah ruangan dan tata letak yang efisien pada lingkungan penyampaian jasa memfasilitasi pemenuhan kebutuhan fungsional dan mempengaruhi kenyamanan pelanggan. Letak kamar tamu yang jauh dari jalan utama sehingga tamu tidak akan merasa bising oleh keramaian Jalan Kuta, akses menuju fasilitas resort yang mudah, penempatan taman-taman tropis di sekitar kamar dan public area serta penggunaan peralatan dan furnitur yang memudahkan proses melayani tamu, hal-hal tersebut membuat tamu mancanegara merasa nyaman selama menginap di Alam Kulkul Boutique Resort Bali.

\subsection{Gambaran Loyalitas Tamu Mancanegara Alam Kulkul Boutique Resort Bali \\ 4.2.1 Loyalitas Tamu Mancanegara Berdasarkan Behavioral}

Indikator loyalitas berdasarkan behavioral atau perilaku yang mendapatkan penilaian tertinggi adalah memberikan rekomendasi kepada orang lain untuk menginap di Alam Kulkul Boutique Resort Bali dengan presentase sebesar 28,1\%. Hal tersebut menandakan bahwa tamu mancanegara yang menginap merasa puas dengan produk dan jasa yang mereka gunakan selama menginap di Alam Kulkul Boutique Resort Bali, sehingga mereka dengan senang hati memperkenalkan dan merekomendasikan kepada pihak lain untuk menginap di Alam Kulkul Boutique Resort Bali.

Penilaian terendah terdapat pada memberikan saran kepada Alam Kulkul Boutique Resort Bali yaitu sebesar 19,2\%. Hal tersebut menunjukkan keinginan tamu untuk membantu hotel untuk menjadi lebih baik masih rendah. Baloglu (2002:50) mengungkapkan, "kerjasama telah didefinisikan sebagai suatu kerjasama untuk mencapai tujuan bersama dan juga sebuah keinginan pelanggan untuk membantu perusahaan." Salah satu bentuk kerjasama tersebut adalah pemberian saran kepada perusahaan itu sendiri.

Loyalitas Tamu Mancanegara Berdasarkan $\underline{\text { Attitudinal }}$ 
Indikator loyalitas berdasarkan attitudinal atau sikap yang mendapatkan penilaian tertinggi adalah kepercayaan terhadap produk dan jasa yang ditawarkan Alam Kulkul Boutique Resort Bali dengan presentase sebesar 41,2\%. Hal itu dikarenakan Alam Kulkul Boutique Resort Bali senantiasa memberikan pelayanan jasa yang terbaik dan mampu memenuhi keinginan dan kebutuhan tamu mancanegara selama menginap maupun melakukan aktivitas. Selain itu produk yang digunakan untuk kebutuhan tamu mancanegara juga menggunakan bahan-bahan terbaik sehingga dapat memberikan kepuasan kepada tamu mancanegara yang menggunakannya.

Sementara itu, biaya peralihan (waktu, biaya, dan usaha) yang harus dikeluarkan jika ingin menggunakan produk atau jasa pesaing mendapatkan penilaian terendah yaitu sebesar 25,6\%. Hal tersebut disebabkan oleh banyaknya pilihan hotel sejenis (bintang 4) maupun yang tidak sejenis di lokasi sekitar Alam Kulkul Boutique Resort Bali. Letak hotel yang berdekatan, fasilitas yang hampir sama dan penawaran harga yang kompetitif membuat tamu mancanegara dengan mudah memilih hotel yang sesuai dengan kebutuhan dan keinginannya, kemudian beralih menggunakan jasa dari hotel lain.

\subsubsection{Rekapitulasi Tanggapan Tamu Mancanegara Terhadap Loyalitas Alam Kulkul Boutique Resort Bali}

Secara ideal skor yang diharapkan untuk jawaban tamu loyal mancanegara terhadap pertanyaan 1 sampai dengan 7 adalah 3500 . Dari perhitungan diperoleh total skor sebesar 2410 atau $68,9 \%$ dari skor ideal yaitu 3500 . Hasil tersebut menunjukkan bahwa tanggapan terhadap loyalitas tamu mancanegara secara keseluruhan berada pada kategori tinggi.

\subsubsection{Tahapan Loyalitas Tamu Mancanegara di Alam Kulkul Boutique Resort Bali}

Tanggapan tamu mancanegara Alam Kulkul Boutique Resort Bali dapat diklasifikasikan ke dalam jenis tingkatan loyalitas, salah satunya menurut Baloglu (2002: 48-50) yang membagi tingkat loyalitas menjadi empat jenis dimulai dari yang paling rendah yaitu low loyalty, latent loyalty, spurious loyalty, dan true loyalty. Berdasarkan jawaban tamu mancanegara Alam Kulkul Boutique Resort Bali dapat dilakukan perhitungan sehingga pengklasifikasian tingkat loyalitas tamu mancanegara dapat dilakukan. Adapun perhitungan dilakukan dengan mengacu pada juranal Baloglu tahun 2002 yang berjudul "Dimensions of Customer Loyalty: Separating Friends from Well Wishers" dimana perhitungan dimulai dengan analisis kluster, MANOVA kemudian dilanjutkan dengan analisis diskriminan. Seluruh perhitungan dibantu dengan menggunakan software PASW Statistics 18.

Dari 100 tamu mancanegara yang dijadikan responden penelitian, kluster 3 yang terdiri 20 orang tamu menunjukkan karakteristik true loyalty dengan tingkat attitudinal dan behavioral yang tinggi. Karakteristik spurious loyalty ditemukan pada kluster 2 yang memiliki tingkat behavioral yang tinggi dan attitudinal yang rendah. Kluster ini memiliki jumlah anggota paling tinggi diantara kluster-kluster lainnya yaitu sebanyak 60 orang tamu atau $60 \%$ dari keseluruhan sampel. Sementara jumlah anggota paling sedikit terdapat pada kluster 1 yang memiliki karakteristik latent loyalty sebanyak 8 orang tamu (8\%). Latent loyalty merupakan loyalitas yang memiliki tingkat attitudinal yang tinggi namun tingkat behavioral rendah. Tingkat paling rendah yaitu low loyalty dimana tingkat attitudinal dan behavioral menunjukkan tingkat yang rendah. Karakteristik tersebut ada pada kluster 4 dengan jumlah anggota sebanyak 12 orang tamu atau $12 \%$ dari seluruh sampel penelitian.

Untuk itu dapat disimpulkan bahwa tamu mancanegara yang menginap di Alam Kulkul Boutique Resort Bali sebagian besar berada pada tingkat spurious loyalty (60 orang tamu). Hal itu ditunjukkan dari tingkat behavioral yang tinggi namun tingkat attitudinal tamutamu tersebut rendah. Tabel 4.20 menunjukkan tamu mancanegara dengan karakteristik spurious loyalty memiliki frekuensi menginap yang tinggi dan sering memberikan rekomendasi kepada orang lain untuk menginap di Alam Kulkul Boutique Resort Bali namun biaya peralihan (waktu, biaya, dan tenaga) yang rendah dan komitmen yang juga rendah menunjukkan bahwa tamutamu tersebut memiliki tingkat atttitudinal yang rendah.

\subsection{Pengaruh Servicescape Terhadap Loyalitas Tamu Mancanegara di Alam Kulkul Boutique Resort Bali}

Berdasarkan hasil matriks korelasi antara sub variabel servicescape terhadap loyalitas, diperoleh hasil korelasi secara berurutan yaitu, ambient conditions $(0,813)$, spatial layout and functionality $(0,878)$, dan signs symbols and artifacts $(0,735)$. 
Berdasarkan hasil matriks korelasi pengaruh langsung antara tiga sub variabel $\mathrm{X}$ dan variabel $Y$ yang memiliki korelasi terbesar adalah spatial layout and functionality dengan loyalitas yaitu sebesar 0,878. Jika diinterpretasikan menurut Suharsimi (2009:245) maka tingkat korelasi variabel spatial layout and functionality adalah sangat tinggi karena berkisar antara 0,700-1,00. Sementara koefisien korelasi terkecil ada pada antara sub variabel signs, symbols and artifacts dengan loyalitas sebesar 0,735. Namun koefisien korelasi tersebut masih terhitung tinggi, karena berada di antara 0,700-1,00 (Suharsimi 2009:245).

Berdasarkan hasil korelasi selanjutnya pengujian keseluruhan dilakukan untuk melihat pengaruh servicescape yang terdiri dari ambient conditions, spatial layout and functionality dan signs, symbols and artifacts terhadap loyalitas secara keseluruhan yang dilakukan melalui uji $\mathrm{F}$ dengan menggunakan program PASW Statistics 18. Berdasarkan perhitungan Uji $\mathrm{F}$ diperoleh nilai $\mathrm{F}_{\text {hitung }}=$ 154,981 sedangkan $F_{\text {tabel }}$ dengan derajat kebebasan pada $\alpha(0,10)$ adalah sebesar 2,142 dengan demikian $F_{\text {hitung }}(154,981)>F_{\text {tabel }}$ $(2,142)$ dengan nilai signifikansinya 0,000 . Nilai signifikansi lebih kecil dari taraf signifikansi $10 \%$, sehingga jelas $\mathrm{H}_{0}$ ditolak dan $\mathrm{H}_{\mathrm{a}}$ diterima. Untuk itu dapat diambil kesimpulan bahwa secara keseluruhan model fit dan bisa dilakukan uji parsial.

Berdasarkan hasil pengujian koefisien jalur, total pengaruh servicescape terhadap loyalitas tamu mancanegara Alam Kulkul Boutique Resort Bali yaitu sebesar 0,829 atau $82,9 \%$. Servicescape yang memiliki pengaruh paling tinggi yaitu dari dimensi spatial layout and functionality (X2) dengan total pengaruh sebesar 0,423 atau 42,3\%. Sementara signs, symbols and artifacts (X3) memberikan total pengaruh terhadap loyalitas dengan nilai terendah yaitu sebesar 0,123 atau $12,3 \%$.

Berdasarkan hasil perhitungan di atas maka pengaruh servicescape terhadap loyalitas tamu mancanegara di Alam Kulkul Boutique Resort Bali termasuk kategori cukup kuat. Untuk koefisien jalur variabel lainnya diluar variabel X1 sampai X3 ditentukan melalui:

$$
\begin{aligned}
\mathrm{P}_{\mathrm{Z} €} & =\sqrt{1-R^{2} y(x 1.1, x 1.2, x 1.3)} \\
& =\sqrt{1-0,829} \\
& =0,414
\end{aligned}
$$

Hal tersebut berarti bahwa X1 sampai X3 secara bersama-sama mempengaruhi loyalitas adalah sebesar $82,9 \%$ dan sisanya sebesar $(0,414)^{2}=0,171 \times 100 \%=17,1 \%$ dipengaruhi oleh faktor lain yang tidak termasuk dalam penelitian ini.

Berdasarkan hasil temuan penelitian penulis memperkuat teori Lovelock dan Writz (2011:284-290) yang menyatakan bahwa karakteristik servicescape yaitu ambient conditions, spatial layout and functionality dan signs, symbols and artifacts. Berdasarkan hasil penemuan penelitian penulis memperkuat konsep loyalitas. Loyalitas terdiri dari attitudinal dan behavioral (Baloglu 2002:50-51). Menurut Baloglu (2002:47) loyalitas merupakan sikap dan perilaku pelanggan yang menunjukkan adanya pembelian berulang akan suatu barang atau jasa selain itu juga menunjukkan komitmen yang tinggi pada merek atau perusahaan tersebut. Servicescape memiliki pengaruh terhadap loyalitas. Dengan demikian temuan penulis mengukuhkan premis-premis yang dikemukakan oleh Wakefield dan Blodgett (1994:69), Dube \& Renaghan (Alsaqre et al. 2010:255-256), Alsaqre et al. (2010:260), Han dan Ryu (2009:514) dan Bitner (Simpeh et al. 2011:121).

\section{KESIMPULAN DAN SARAN}

\subsection{Kesimpulan}

Servicescape di Alam Kulkul Boutique Resort Bali mendapatkan penilaian yang baik dari tamu mancanegara sesuai dengan garis kontinum servicescape yang berada dalam kategori tingkat yang tinggi. Sub variabel yang mendapatkan penilaian tertinggi adalah spatial layout and functionality. Hal tersebut dikarenakan tamu mancanegara merasa nyaman dengan denah ruangan yang didesain oleh pihak Alam Kulkul Boutique Resort Bali dan tingginya daya tarik desain interior private area (kamar). Sementara itu, penilaian terendah diperoleh sub variabel signs, symbols and artifact karena tamu mancanegara merasa logo yang dimiliki Alam Kulkul Boutique Resort Bali tidak begitu menarik begitu juga dengan kejelasan pesan yang disampaikan behavioral rules sign yang dinilai kurang jelas bagi para tamu mancanegara.

Loyalitas tamu mancanegara di Alam Kulkul Boutique Resort secara umum berdasarkan garis kontinum berada pada tingkat tinggi. Dari kedua karakteristik tersebut indikator behavioral mendapatkan nilai tertinggi. Hal tersebut dikarenakan tingginya frekuensi tamu mancanegara untuk menginap kembali dan tingginya frekuensi mereka melakukan rekomendasi kepada orang lain untuk menginap di Alam Kulkul Boutique 
Resort Bali. Sementara indikator attitudinal yang terdiri dari kepercayaan, komitmen dan biaya peralihan mendapatkan nilai terendah. Rendahnya penilaian pada biaya peralihan menunjukkan tamu mancanegara dapat dengan mudah pindah ke hotel lain karena beragamnya pilihan hotel yang memiliki produk atau jasa hampir serupa dengan harga yang lebih murah.

Sesuai dengan akumulasi perhitungan loyalitas berdasarkan indikator behavioral dan attitudinal, tingkat loyalitas yang dimiliki sebagian besar tamu mancanegara di Alam Kulkul Boutique Resort Bali ada pada tingkat spurious loyalty yang memiliki karakteristik tingkat behavioral tamu yang tinggi dan tingkat attitudinal yang rendah. Sementara tingkat loyalitas paling rendah yaitu low loyalty yang bercirikan tingkat attitudinal dan behavioral yang rendah dimiliki oleh 12 orang tamu mancanegara.

Penelitian menunjukkan bahwa sevicescape yang terdiri dari ambient conditions, spatial layout and functionality dan signs, symbols and artifacts berpengaruh terhadap loyalitas tamu mancanegara di Alam Kulkul Boutique Resort Bali. Sehingga dapat ditarik kesimpulan bahwa semakin tinggi tanggapan tamu mancanegara terhadap servicescape maka semakin tinggi loyalitas tamu mancanegara Alam Kulkul Boutique Resort Bali.

\subsection{Rekomendasi}

Pihak manajemen Alam Kulkul Boutique Resort Bali harus lebih memperhatikan kenyamanan suhu di public area (Spa, lobby, restoran, AlamClub dll). Manambah unit dan mengatur suhu air conditioning yang lebih rendah pada ruangan tertutup dan penggunaan outdoor air conditioning/fan di ruangan terbuka dapat membantu menyejukkan udara. Selain itu, sebaiknya pihak manajemen Alam Kulkul Boutique Resort Bali menggunakan furnitur yang lebih menarik dan unik di public area (Spa, lobby, restoran, AlamClub dll), memberikan petunjuk behavioral rules sign yang lebih jelas dengan meletakkan tanda petunjuk tersebut di tempat yang mudah dilihat oleh tamu. Terakhir, pembuatan logo baru yang lebih menarik juga diperlukan, sehingga tamu dapat dengan mudah mengenali dan mengingat resort walaupun hanya dengan melihat gambar logo resort.

Berdasarkan tingkatan loyalitas, meskipun tingkat low loyalty hanya terdiri dari 12 orang, pihak manajemen Alam Kulkul Boutique Resort Bali harus membuat strategi agar jumlah tersebut mengecil dan tamu-tamu pada tingkat loyalitas tersebut dapat naik ke tingkat yang lebih tinggi bahkan hingga mencapai true loyalty. Penulis merekomendasikan pihak manajemen Alam Kulkul Boutique Resort Bali memberikan inovasi pada produk dan jasa di Alam Kulkul Boutique Resort Bali yang tidak dimiliki kompetitor. Sehingga dapat meningkatkan biaya peralihan dan membuat tamu mancanegara terus kembali menginap di Alam Kulkul Boutique Resort Bali. Selain itu, memberikan kesempatan kepada tamu untuk memberikan saran kepada pihak manajemen resort juga diperlukan untuk meningkatkan pelayanan kepada tamu. Hal tersebut dapat dilakukan oleh staf operasional dengan menanyakan pendapat tamu mengenai produk dan jasa yang telah digunakannya atau menambah frekuensi acara cocktail party yang mempertemukan staf resort dengan tamu yang menginap.

Servicescape secara umum terbukti dapat mempengaruhi loyalitas tamu mancanegara. Sub variabel yang mendapatkan nilai tertinggi yaitu spatial layout and functionality. Untuk itu untuk meningkatkan loyalitas tamu mancanegara Alam Kulkul Boutique Resort Bali harus lebih memperhatikan indikatorindikator pada sub variabel tersebut terutama indikator yang mendapatkan penilaian tertinggi. Indikator tersebut diantaranya daya tarik desain interior dan denah ruangan di Alam Kulkul Boutique Resort Bali. Diharapkan pihak resort dapat terus konsisten dengan konsep jasa yang sudah ada (natural and traditional of Bali) dan terus menjaga desain interior private area agar tetap terlihat menarik namun tidak melupakan aspek kenyamanan para tamu. Begitu juga dengan denah ruangan yang ada diharapkan dapat dipertahankan atau lebih ditingkatkan lagi kenyamanannya dengan memperhatikan faktor-faktor aksesibiltas, kemudahan dan efisiensi proses penyampaian jasa.

Keterbatasan dalam penelitian ini yaitu peneliti hanya melakukan penelitian dengan survei kepada tamu mancanegara yang telah menginap secara berulang saja. Rekomendasi untuk peneliti berikutnya diharapkan dapat meneliti keseluruhan tamu yang menginap di Alam Kulkul Boutique Resort Bali baik yang sudah menginap secara berulang maupun first time guest dan meneliti variabel lain yang berpengaruh terhadap loyalitas seperti service quality, service convinience, experiental marketing dan lainnya. 


\section{DAFTAR PUSTAKA}

Achmad, Engkos dan Riduwan. 2008. Cara menggunakan dan Memaknai Analisis Jalur. Alfabeta: Bandung.

Ali Hasan, 2009. Marketing. Yogyakarta: Media Pressindo.

Alsaqre, Omar E., Mohamed, Badaruddin dan Jaafar, Mastura. 2010. A Study of the Effects of Factors in the Physical Environment of Hotels on Customer's Perception of Service Quality and Loyalty. Journal of School of Housing, Planning and Building, pp. 254-263.

Baloglu, Seyhmus. 2002. Dimensions of Loyalty - Separating Friends From Well Wishers. Cornell Hotel and Restaurant Adminstration Quarterly 2002, pp.47-59.

Bright, Alan D. 2000. The Role of Social Marketing in Leisure and Recreation Management. Journal of Leisure Research, Vol. 32, No. 1, pp. 12-17.

Fandy Tjiptono, 2006. Pemasaran Jasa. Bayu Media Publishing: Jawa Timur.

Gilaninia, Shahram. et al. 2011. Relationship Marketing: a New Approach to Marketing in the Third Millennium. Australian Journal of Basic and Applied Sciences 5(5): pp. 787-799.

Griffin, Jill. 2005. Customer Loyalty: Menumbuhkan dan mempertahankan Kesetiaan Pelanggan. Jakarta: Erlangga.

Hall,CM and Mirchell. 2008. Wine Marketing : A Practical Approach. Oxford: Butterworth Heinemann

Han, Hesup dan Ryu, Keesang. 2009. The Roles Of The Physical Environment, Price Perception,And Customer Satisfaction In Determining Customer Loyalty In The Restaurant Industry. Journal of Hospitality \& Tourism Research, Vol. 33, No. 4, pp. 487-510

Harris, L.C dan Ezeh, Chris. 2008. Servicescape and Loyalty Intentions: an Empirical Investigation. European Journal of Marketing Vol.42, No. 3/4, pp.390-422.

Hightower, R., Shariat, M. 2009. Servicescape's Hierarchical Factor Structure Model. Global Review of Business and Economic Research, Vol. 5 No. 2, pp. 375-398

Hoffman, K.Doglas.,dan Bateson, John E.G. 2011. Service Marketing: Concept, Strategies \& Cases. South-western College.
Kotler, Philip dan Kevin L. Keller. 2011. Marketing Management, 14th edition. New Jersey: Pearson Prentice Hall.

Kotler, Philip dan Gary Armstrong. 2011. Principles of Marketing. New Jersey: Pearson Prentice Hall.

Jonathan Sarwono. 2010. PASW Statistics 18. Yogyakarta: Andi.

Lovelock, and Wright. 2007. Manajemen Pemasaran Jasa Edisi Bahasa Indonesia. PT. INDEKS.

Lovelock, and Wirtz. 2011. Service Marketing: People, Technology, Strategy 7th Edition. New Jersey: Pearson.

Ratih Huriyati. 2008. Bauran Pemasaran dan Loyalitas Konsumen. Bandung : Alfabeta.

Russel, Edward. 2010. The fundamental of marketing. Ava Book Production. Ltd. Singapore

Simpeh, K.N. et al. 2011. Servicescape and Customer Patronage of Three Star Hotels in Ghana's Metropolitan City of Accra. European Journal of Business and Management Vol. 3, No.4, pp.119131.

Sugiyono. 2008. Metode Penelitian Kuantitatif Kualitatif dan R\&D. Bandung: Alfabeta.

Sugiyono. 2008. Metode Penelitian Bisnis. Bandung: Alfabeta.

Suharsimi Arikunto. 2009. Manajemen Penelitian. Jakarta: Rineka Cipta.

Ulber Silalahi. 2009. Metode Penelitian Sosial. Bandung: Refika Aditama

Vanessa Gaffar. 2007. CRM dan MPR Hotel. Bandung: Alfabeta

Wakefield,K.L and Blogett,JG .1996. The Effect of The Servicescape on Customers' Behavioral Intentions in Leisure Service Settings". Journal of Service Marketing Vol.10 No.6. pp 46

Zeithaml, A. Valerie, et al.,2009. Services Marketing: Integrating Customer Focus Across The Firm 5th International edition. Singapore: McGraw Hill.

\section{Situs internet:}

Bali Hotel Market Overview First Half 2011 by Knight Frank. http://my.knightfrank.com/research/?re gionid=5. (6 Februari 2012)

Jumlah Kedatangan Wisman Ke Indonesia Berdasarkan Pintu Masuk Tahun 20062011. http://www.parekraf.go.id/budpar/asp/d 
etil.asp?c $=87 \&$ id $=979$. ( 2 Februari 2012)

King, Rhianna. 2012. WA Holidays 'Can't Compete' with Cheap Bali. [Online]

http://www.watoday.com.au/wa-news/waholidays-cant-compete-with-cheapbali-20120207-1r4a4.html (4 Mei 2012)

Drewer,P. 2005. Key Note Market Report Plus: Hotels (20th Edition). [Online]. www.keynote.co.uk (21 Oktober 2010)

Ni Luh Made Pertiwi F. (2011, 30 Desember). Tema 2012: "Green and Creative Tourism". Kompas. [Online]. http://travel.kompas.com/read/2011/12/ 30/17522517/Tema.2012.Green.and.Cr eative.Tourism. (30 Desember 2011)

Perkembangan Tingkat Penghunian Kamar (TPK) hotel bintang 4 di Bali dari tahun 2005-2009.

http://www.baliprov.go.id/ind- ex.php?page $=$ statistik_pariwisata $(26$

Oktober 2009)

The Travel and Tourism Competitiveness Report 2011.

http://www.weforum.org/reports/travel -tourism-competitiveness-report-2011 (24 Januari 2012)

Tingkat Penghunian Kamar Hotel Bintang Tahun 2010 vs 2011. www.budpar.go.id/filedata/6927_2488 TPKAgustus2011.pdf (27 September 2011)

UNWTO Tourism Highlights 2011. http://mkt.unwto.org/sites/all/files/docp df/unwtohighlights11enhr_1.pdf (26 September 2011)

UNWTO Barometer January 2012 Edition. http://www.scribd.com/doc/78519219/ UNWTO-World-Tourism-BarometerJanuary-2012. ( 19 Januari 2012) 